\title{
Enhancing Language Learning and Acquisition by Implementing Extensive Reading
}

\section{(El enriquecimiento del aprendizaje y de la adquisición mediante la lectura extensiva)}

Ana Rojas Ugalde ${ }^{2}$

Universidad Nacional, Costa Rica

Vivian Vargas Barquero 3

Universidad Nacional, Costa Rica

\begin{abstract}
An explanation is provided of how extensive reading was used in the secondyear reading courses in two majors - the Teaching of English as a Foreign Language (Bachillerato en la Enseñanza del Inglés, BEI) and English as a Foreign Language (Bachillerato en Inglés, BI), both of the Universidad Nacional (Heredia, Costa Rica) - to improve their language proficiency. To implement this, the time and activities were organized in student-centered sessions so that the learners could select readings for their individual use.

\section{RESUMen}

Se explica cómo se utilizó la lectura extensiva en los cursos de lectura con estudiantes de segundo año en el Bachillerato en Inglés y Bachillerato en la Enseñanza del Inglés en la Universidad Nacional (Heredia, Costa Rica), para mejorar su competencia lingüística. Para su puesta en ejecución, se organizó el tiempo y las actividades centradas en el alumno, con el fin de que escogieran las lecturas para su uso individual.
\end{abstract}

1 Recibido: 3 de setiembre de 2019; aceptado: 30 de abril de 2020.

2 Escuela de Literautra y Ciencias del Lenguaje. Correo electrónico: ana.rojas.ugalde@una.cr

3 Escuela de Literautra y Ciencias del Lenguaje. Correo electrónico: vivian.vargas.barquero@una.ac.cr

LETRAS 69 (2021), ISSN 1409-424X; EISSN 2215-4094 
Keywords: extensive reading, learning, language, pleasure reading, proficiency level, motivational factors

Palabras clave: lectura extensiva, aprendizaje, lengua, lectura placentera, competencia lingüística, factores motivacionales

A book is a dream that you hold in your hand

NeIL Gaiman

\section{Introduction}

Achieving an optimal level of proficiency by the end of a language instruction program is the aim of most language learners. During those years, the real challenge is how the instructors can find ways to lead the students to success. To receive any kind of output from students, they must exposed to the language. Even though this aspect is so relevant, receptive skills connected to input (reading/ listening) often appear to be considered less important than productive skills related to output (speaking/writing). Without input, there probably will be no output either; the amount and level of difficulty of input can influence the students' output. Language studies have suggested that attention to reading can lead to improve performance in processing input and increased accuracy in production. ${ }^{4}$ Following this premise, these questions arise: How can students' language proficiency be improved through extensive reading? And how much exposure can make a significant language improvement?

To explore these research questions, and confirm the above statements, extensive reading techniques were used with second-year undergraduate students in the majors of the Teaching of English as a Foreign Language (Bachillerato en la Enseñanza del Inglés, BEI) and English as a Foreign Language (Bachillerato en Inglés, BI) at Universidad Nacional (UNA, Heredia, Costa Rica) in the courses

4 Beniko Mason and Stephen Krashen, "Extensive Reading in English as a Foreign Language," System 25, 1 (1997): 91-102. DOI: https://doi.org/10.1016/S0346-251X(96)00063-2; Made F. Yulia. "Extensive Reading in L2 Learning: Current Trends and Future Possibilities," Premise Journal 7, 1 (2018): 36-48. DOI: http://dx.doi.org/10.24127/pj.v7i1.1293. 
of "Reading" and "Reading Techniques" during the second term of 2018. The aim of this research was to implement extensive reading as an approach to improve language competence and performance by incorporating classroom reading. A primary concern of extensive reading is to motivate students to read for pleasure in and outside the classroom environment as a consistent practice that could potentially lead students to acquire a habit of reading, and consequently foster language learning.

\section{Extensive Reading as a Language Approach}

This section provides a general overview of the origins and current trends of the reading approach called extensive reading (ER), beginning with a consensual definition by language scholars. Secondly, it addresses the top ten ER teaching principles proposed by Day and Bamford, ${ }^{5}$ and finally, it describes the main benefit of ER for language learners. This section will address the theoretical background of the field and set the foundation and reasoning for the study carried out.

\section{Definition of Extensive Reading}

Reading, listening, speaking and writing are the fourmain language skills implemented when learning and teaching a foreign language. Thus, reading is classified as a receptive skill and plays a vital role in the process of connecting texts, readers, social contexts and meanings. Along the same lines, there are four widely used techniques for teaching reading to language learners: skimming, scanning, intensive and extensive reading. Both skimming and scanning are quick-thinking reading strategies; the former focuses on tracing details or clues in a text, and the latter centers on getting the gist or general overview of a text. Intensive reading is an in-depth strategy that considers an understanding of the text as the core of reading, as it focuses on meaning as constructed by

5 Richard R. Day and Julian Bamford, “The Characteristics of an Extensive Reading Approach,” Extensive Reading in the Second Language Classroom (New York: Cambridge University Press, 2012) 7. 
means of grammatical forms, and ideas are related to one another by means of discourse markers. Lastly, the ER technique, the core of the present analysis, strives for achieving wide-ranging understanding at the surface level by skipping unfamiliar words to avoid interrupting the flow of reading and comprehension. ${ }^{6}$

Richard R. Day and Julian Bamford, two of the main advocates of ER, define this approach as:

... an approach to language teaching in which learners read a lot of easy material in the new language. They choose their own reading material and read it independently of the teacher. They read for general, overall meaning, and they read for information and enjoyment. They are encouraged to stop reading if the material is not interesting or if it is too difficult. They are also encouraged to expand their reading comfort zone - the range of material that can be read easily and with confidence. ${ }^{7}$

As stated above, ER aims to help language learners to develop and improve micro language skills such as vocabulary, grammar and fluency inductively by engaging learners in reading for pleasure. This approach is characterized by having the freedom to choose reading materials for activities in which a large amount of effortless reading is timed and organized during the class period. Additionally, ER does not focus on exploiting texts but rather on joyful, fast and silent reading. ${ }^{8}$

6 Iwan Fauzi, "The Effectiveness of Skimming and Scanning Strategies in Improving Comprehension and Reading Speed Rates for the Students of English Study Program," Register Journal 11, 1 (2018): 101-120 (104-106). DOI: https://doi.org/10.18326/rgt.v11i1.101-120.

7 Richard R. Day and Julian Bamford, "Introduction," Extensive Reading Activities for Teaching Language (Cambridge: Cambridge University Press, 2014) 1.

8 Richard R. Day and Julian Bamford, "Extensive Reading in the Second Language Classroom," RELC Journal 29, 2 (1998): 187-191. DOI: https://doi.org/10.1177/003368829802900211; Maria Pigada and Norbert Schmitt, "Vocabulary Acquisition from Extensive Reading: A Case Study," Reading in a Foreign Language 18, 1 (2006): 1-28; Juan Pino-Silva, "Extensive Reading through the Internet: Is It Worth the While?," International Journal of English Studies 9, 2 (2009): 81-96. DOI: https://doi.org/10.6018/ijes.9.2.90761; Made F. Yulia, "Extensive Reading in L2 Learning: Current Trends and Future Possibilities," Premise Journal 7, 1 (2018): 36-48. DOI: https://doi. org/10.24127/pj.v7i1.1162 
Going back to 1954, Harold Palmer (as quoted by Kelly) is said to be the first scholar to apply ER strategies, claiming that "reading may be extensive... [in which] ...book after book will be read through without giving more than a superficial and passing attention to the lexicological units of which it is composed." $\mathrm{By}$ applying empirical ER techniques, Palmer sought to teach learners about the target culture and facilitate the reading and understanding of literary works such as the Bible.

\section{Top Ten ER Teaching Principles}

In 1998, Day and Bamford proposed ten characteristics and/or principles that operate effectively in ER programs. These ER guiding principles are implemented as good practices in successful ER programs and intend to support teachers while they examine their beliefs behind teaching reading strategies. The intention is to eliminate common problems faced in the EFL classroom when reading in the target language. The ten principles are briefly detailed here: (1) there should be as much reading as possible; (2) an ample scope of topics and materials should be offered; (3) reading materials are based on students' choices; (4) reading time is pleasurable; (5) reading is seen as a self-retribution; (6) reading does not go beyond students linguistic competencies; (7) reading is done silently and independently; (8) reading is fast-paced; (9) reading is tracked and guided by the teacher; and (10) modeling is the role of the teacher. ${ }^{10}$ These prime principles serve as a methodological departure point to put ER into action in the classroom. In 2002, Day and Bamford provided further explanations on these features, stating that reading materials should not necessarily be limited to simple texts. They provided conclusive evidence that

9 Louis G. Kelly, "Part II. Making the Language a Habit," 25 Centuries of Language Teaching (Rowley, MA: Newbury House, 1969) 89-180 (131).

10 Richard R. Day and Julian Bamford, Extensive Reading in the Second Language Classroom (New York: Cambridge University Press, 1998) 7-8. 
longer texts can be useful if learners are allowed to select books on topics that they find attention-grabbing. ${ }^{11}$

The reading texts are carefully chosen to maintain the students' interest and take into account their preferences. A wide variety of texts can be selected according to the students' level of language proficiency; the books are classified into groups of difficulty considering length, number of words, type of vocabulary and grammatical structures. Students start reading books from a basic level and move at their own speed to other levels as soon as they feel confident. They are allowed to stay at the level that fits them best. ER is also useful in developing good reading habits inside and outside of class.

\section{Benefit of Using Extensive Reading in the Classroom}

Jan Hulstijn refers to implicit and explicit learning as a relevant benefit that ER brings to language learners. He puts forth the premise that L1 acquisition occurs in a predominantly implicit way while the acquisition of L2 relies on both implicit and explicit input. ${ }^{12}$ With this idea in mind, ER attempts to integrate what learners already know and spread it to other linguistic domains. The limited classroom time to practice the target language, as noted by Ewert, ${ }^{13}$ tends to slow down the learning process since students depend heavily on their native language for social encounters and activities outside class. Accordingly, ER supports L2 learning by building a sense of learner autonomy, enhancing background learning and providing learning opportunities where learners take control of their pace and language skills improvement. This fact is strengthened by Henri Holec who asserts that "autonomy is very much related to the ability of the learner

11 Julian Bamford and Richard R. Day, “Top Ten Principles for Teaching Extensive Reading," Reading in a Foreign Language 14, 2 (2002): 136-141.

12 Jan H. Hulstijn, "Theoretical and Empirical Issues in the Study of Implicit and Explicit SecondLanguage Learning," Studies in Second Language Acquisition 27, 2 (2005): 129-140. DOI: https:// doi.org/10.1017/S0272263105050084.

13 Doreen Ewert, "The Effects of Extensive Reading on Adult Reading Behavior and Proficiency in an Intensive English Program," Extensive Reading World Congress Proceedings 1 (2012): 141-144. 
to take control of his own learning" (qtd. in Little). ${ }^{14}$ This same notion was proposed by Krashen ${ }^{15}$ who pointed out that ER pays off in voluntary reading. Further, ER enables students to become confident, independent readers through class reading time.

\section{Methodology}

The investigation carried out is a qualitative study in which it is intended to obtain data in order to analyze the effect ER has on a specific group. This purpose has been clearly identified by researchers. For Crossman, "this type of research has long appealed to social scientists because it allows the research to investigate the meanings that people attribute to their behavior, actions, and interactions with others. ${ }^{.16}$ In addition, the approach used is phenomenological, which refers to a "qualitative research method that is used to describe how human beings experience a certain phenomenon."17

Regarding the population, two groups were part of the research: second-year university students in the courses "Reading" and "Reading Strategies" (29 students and 20 students respectively) as described above. An initial survey was applied to this population to gather data on the role that reading plays for each of the students considering factors such as how fond they are of reading, what types of texts they prefer, and what language they prefer for reading. The instrument was designed as a closed-ended survey with only two open-ended questions.

The students also took a test called the Edinburgh Project on Extensive Reading Placement Progress Test (EPER)..$^{18}$ This exam

14 David Little, "Learner Autonomy and second/Foreign Language Learning," LLAS Centre for Languages, Linguistics and Area Studies, 8 April 2019, <https://www.llas.ac.uk/resources/gpg/1409>.

15 Stephen Krashen, "The Role of the First Language," Second Language Acquisition and Second Language Learning. (Oxford: Pergamon Press, 1983) 5.

16 Ashley Crossman, "An Overview of Qualitative Research Methods,” ThoughtCo, 20 March 2019, $<$ https://www.thoughtco.com/qualitative-research-methods-3026555>.

17 "Phenomenology Research Overview," Center for Innovation in research and teaching. Grand Canyon University, Arizona, 20 March 2019, <https://cirt.gcu.edu>.

18 This EPER test is not of public use and access, so permission for it to be applied must be requested by contacting ER foundation scholars through this website: https://erfoundation.org/wordpress/. 
was provided by the ER specialist Doreen Ewert, who delivered a workshop on this topic at Universidad Nacional, Heredia. ${ }^{19}$ She is a member of the Extensive Reading Foundation through which this test is made accessible to members. This exam is not for public use but can be requested from a member of the foundation. It consists of a set of gap-filling passages to be completed with high frequency words. Each passage increases in difficulty as the student advances. The participants in the study took the test at the beginning of the course and then again after the ER sessions were completed.

Once the initial information from the surveys and tests was gathered, various activities were carried out in the class to appraise the students' reading comprehension and analyze the impact ER could have on the groups. For this purpose, three tasks were designed and implemented. The first is a Reading Log; each student was provided a printed reading record sheet, and everyone was asked to keep track of the books, dates, times and comments about their reading progress. The second was Book Chats, where class time was devoted to retelling some interesting stories, facts, characters, settings, plots and impressions of one of the stories. The third was A Reading Presentation where students could creatively represent their favorite book, using a poster or a new cover page, for instance. This representation was shared with students from another course where they retold the story and explained their work. Finally, the students discussed the stories and shared their perceptions of each other's work.

\section{ER in the Classroom}

First, students had the opportunity to read in class 25 minutes twice a week for two months (August and September), for a total of 10 hours. The books were chosen, by UNA instructors with over 10 years of experience, based on the course syllabus according to the level students generally have when taking these courses. Overall,

19 Doreen Ewert, Extensive Reading ER Workshop (Heredia, Costa Rica June 20-21, 2018). 
these are learners are able to communicate albeit with some grammatical difficulty and are better at understanding written texts and oral input than producing orally. The books amount to 87 sixth-grade books, 56 of which are from Harcourt School Publishers, and 31, from Houghton Mifflin; the former ranging from 959-2678 words, and the latter, from 1615-2896 words. The texts present a variety of topics and can be read easily, that is, complying with two of Richard Day's key principles for practicing ER. Thus, all the students can finish at least one entire book in the twenty-five-minute period provided for reading. The students were required to keep a $\log$ with information about each book (a minimum of 12 books, plus 2 more chosen from any source). This task was called Reading Log and was worth $20 \%$ of the final course grade.

The students also participated in three Book Chats worth $10 \%$ of the final grade, where they were provided space in groups to comment on, analyze and retell the stories in the books. The third and final task was called Reading Presentation." This task was worth $10 \%$ of the final grade and the students were required to choose one of the books that they had read and recreate it with a different outcome. They were given options such as a poster, a blog, a cover page, a poem, a different ending, a flow-up or creating a second part of the book, interviewing a character, or any appropriate proposal of their own.

Finally, at the end of the process, the students completed a survey to gather their opinions about each ER activity carried out in class, and about how their perception toward reading might have changed. The survey included many open-ended questions since the students had to justify most of their answers.

\section{Results}

The process of implementing ER in the class has been enlightening for both students and researchers; the students enjoyed their classes as they were learning and improving, and the investigators confirmed 
the applicability of ER within the learning process. The findings summarized here present the rates of reading improvement between the first and second EPER tests applied to the sample population. These results suggest that implementing ER in the language classroom can serve as a bridge to reading for personal enjoyment. They also help understand the process students go through when reading and how they do this in a second language. The following graphs and charts show the growth rates for BEI and BI students respectively after taking the first and second EPER test. Overall, each graph highlights the results per group. Graph 1 represents the results of the 29 students from the Reading course, and graph 2 shows the results of the 20 students enrolled in the Reading Strategies course. Furthermore, each table reports on the percentage of students from the corresponding graph who showed an increase and distributes it by ranges according to the points where individual students showed improvement in their language proficiency level.

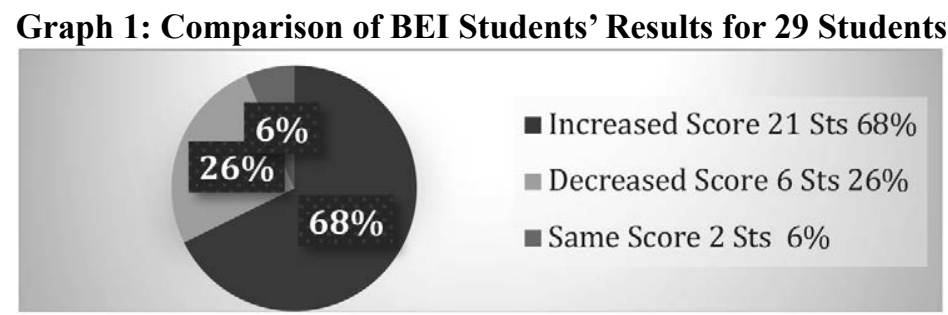

Source: Based on EPER results

Graph 1 presents a holistic view of the total percentages of all BEI students after being part of the ER project. A total of $68 \%$ of the students had better scores in contrast to $26 \%$ who showed a decrease in their results; and a low percentage of only $6 \%$ ( 2 students) did not show any difference in their test results. The results show an overall increase in most learners' scores. 
Table 1: BEI Students Who Improved on the EPER Test

\begin{tabular}{|l|c|c|}
\hline \multicolumn{1}{|c|}{ Number of students } & Increase in points & $\begin{array}{c}\text { Percentage of students } \\
\text { showing an increase }\end{array}$ \\
\hline 7 students & $1-2$ points & $22.66 \%$ \\
\hline 6 students & $3-4$ points & $19.42 \%$ \\
\hline 5 students & $5-6$ points & $16.19 \%$ \\
\hline 3 students & $7-8$ points & $9.71 \%$ \\
\hline Total: 21 students & \multicolumn{2}{|}{ Total: $68 \%$} \\
\hline
\end{tabular}

Source: Based on EPER results.

Table 1 breaks down the $68 \%$ illustrated in graph 1 . This percentage corresponds to only 21 students (of 29 students reexamined), who showed progress in their reading performance. This percentage refers to the development of the BEI students whose performance improved between the first and the second time they took the EPER test. The table displays the number of students who improved and the number of points they increased. The outcomes show that a total of 7 students increased by 1-2 points; 6 students, by 3-4 points; 5 students, by 5-6 points; and 3 students improved by 7 to 8 points.

\section{Graph 2: Comparison of BI Students' Results for 20 students}

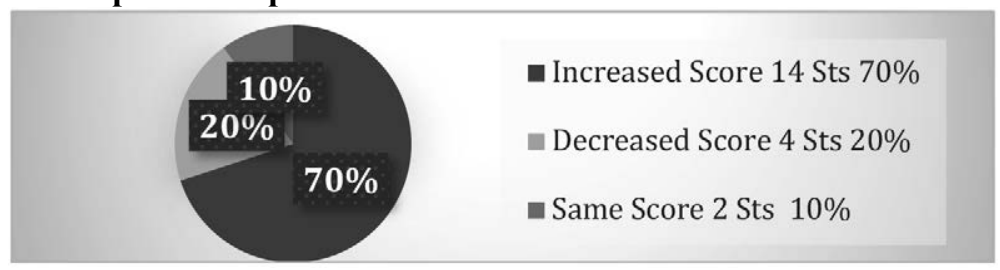

Source: Based on EPER results

Graph 2 accounts for the results of the pre- and post-EPER tests applied to the BI students. Overall, these students showed a tendency to improve, where $70 \%$ accounts for the number of students who increased their scores. On the other hand, $20 \%$ of the students slightly decreased in performance, while $10 \%$ did not vary. 
Table 2: BI Students Who Improved on the EPER Test

\begin{tabular}{|l|c|c|}
\hline \multicolumn{1}{|c|}{ Number of students } & Increase in points & $\begin{array}{c}\text { Percentage of students } \\
\text { showing an increase }\end{array}$ \\
\hline 1 student & $1-2$ points & $5 \%$ \\
\hline 5 students & $3-4$ points & $25 \%$ \\
\hline 3 students & $5-6$ points & $15 \%$ \\
\hline 3 students & $7-8$ points & $15 \%$ \\
\hline 2 students & $9-10$ points & $10 \%$ \\
\hline Total: 14 students & & Total: $70 \%$ \\
\hline
\end{tabular}

Source: Based on EPER results

Table 2 refers to $70 \%$ of the BI students shown in graph 2 . This percentage corresponds only to 14 students of the 20 students reexamined in total, who improved their results the second time the EPER Test was taken. It shows the increase in the number of points for those learners, and the corresponding percentage. In general, 1 student improved by 1-2 points; 5 students, by 3-4 points; 3 students, by 7-8 points; and 2 students improved by as much as $9-10$ points. The results represented in the tables and graphs reveal that most of the students improved their scores after being exposed to ER practices. Thus, these results appear to support Ewert's ${ }^{20}$ claim that improvement occurs in students even with only a little exposure to ER. Considering these findings, it should be analyzed whether constantly implementing this type of activity is a practice that should be included in the curricula.

Regarding students' motivation towards reading, table 3 summarizes the students' appraisals after participating in the ER activities during their reading course.

20 Doreen Ewert, Extensive Reading ER Workshop (Heredia, Costa Rica June 20-21, 2018). 
Table 3: Students' Appraisal of ER Class Activities

\begin{tabular}{|c|c|}
\hline $\begin{array}{l}\text { Students in the Teaching of English } \\
\text { as a Foreign Language major (BEI) }\end{array}$ & $\begin{array}{l}\text { Students in the Bachelors in English } \\
\text { major (BI) }\end{array}$ \\
\hline $\begin{array}{l}\text { I would extend the weeks of } \\
\text { reading time until the end of the } \\
\text { semester. } \\
\text { The reading time was very } \\
\text { satisfactory and interesting. } \\
\text { The reading time is excellent as it is } \\
\text { now, I don't think I need changes. } \\
\text { The reading time was an efficient } \\
\text { time invested. } \\
\text { - I think reading time was very } \\
\text { creative and a beautiful activity. } \\
\text { - I like to have more time for } \\
\text { reading. } \\
\text { - I feel motivated to read outside of } \\
\text { class. } \\
\text { - Reading time was good and } \\
\text { enjoyable. } \\
\text { I like reading silently. It was really } \\
\text { pleasant. }\end{array}$ & $\begin{array}{l}\text { - I think this reading activity is } \\
\text { really well organized and promote } \\
\text { the importance of reading. } \\
\text { The way this activity was carried } \\
\text { out was nice and enjoyable. } \\
\text { - I enjoy reading silently and quietly. } \\
\text { Reading time in class is a good } \\
\text { practice. } \\
\text { - Now I want to read more during } \\
\text { my free time. } \\
\text { I will try to spend more time } \\
\text { reading outside. } \\
\text { I would like to dedicate more time } \\
\text { in class to read. } \\
\text { - I had a great time reading. } \\
\text { I like to choose books that } \\
\text { interested me. }\end{array}$ \\
\hline
\end{tabular}

Source: Based on students' comments

Table 3 highlights enjoyment and motivation as two important outcomes of ER in the classroom. Another reported benefit is students' inclination to start reading outside of class. Lastly, students would like to increase the amount of time devoted to reading in class. After carrying out this reading process, it is evident that students were highly motivated to receive input in a way which did not create a stressful environment. In fact, the instructor should promote the joy of reading. This can be done by simply listening to the students' opinions and by following the ER principles which allow for flexibility and personal growth on the student's behalf. 


\section{Conclusions}

This research presents evidence of the effectiveness of promoting reading through ER in the language classroom to improve students' processing of input and vocabulary significantly. This enables learners to construct meaning by being exposed to an input-rich reading environment which, as a complementary effect, leads to better language-proficiency outcomes. Therefore, this study suggests that ER supports the acquisition of language and the fact that learning without enjoyment is less meaningful. When it comes to the students' commitment to spend time inside and outside of class on educational activities, the tasks must be compelling and enjoyable. Accordingly, learners should be exposed to formal and informal instructional settings where both linguistic and soft skills are practiced.

Additionally, this study is an attempt to explore the implementation of the ER approach by applying pre- and post-tests and an EPER test in two UNA foreign language reading courses. The results revealed that about $70 \%$ of the students increased their performance on the EPER test, and their comments indicate that their motivation towards learning a second language through reading increased. The remaining two categories of students in each group whose score decreased $(26 \%$ and $20 \%$ of the students) and those who retained the same score $(10 \%$ and $6 \%$ of students) are details which require further investigation. However, it is hypothesized that these findings are the result of some students not feeling motivated about taking the same test a second time. Another factor is that at the end of the school term the students are tired and do not want to put effort into an evaluation that does not count for their final grade.

This analysis outlines the methodology and procedures followed to provide students with an initial exposure to reading and to motivate them to continue reading inside and outside the classroom. It also describes a preliminary exploratory study of a reading approach that could to be implemented later by other colleges with other students 
majoring in English. Therefore, the results present a positive initial scenario to be taken into account in further related research and curriculum design.

\section{Limitations and Future Research}

Certain shortcomings and weaknesses were also observed. First, students reported the need to extend the time for the reading period in class. Not all of them reported doing ER during their spare time outside of class. Second, even though students are not expected to understand everything they read, it is essential to provide them with strategies to improve their understanding so that they can get the most out the stories. In addition, for the present research the investigators had to rely on their own stock of materials and story books, but based on the results of this initial study, it is expected that the coordinator of the English department will collect a variety of books of different levels which will be available to students and teachers.

There is substantial information in this research project to contribute to the current and ongoing redesign of the majors' curriculum and open debate on ways to motivate students towards learning, course content and reading strategies. Moreover, these findings provide an initial attempt to discover how ER can be used in our class setting and particular teaching context. More research is required so that an ER program can be designed to motivate students to continue reading inside and outside of class. 
